\title{
Monetary Restraint and Inflationary Momentum
}

HE ECONOMY is showing the continuing effects of the policies of monetary and fiscal restraint actively pursued during the past year. The rate of growth of total spending has slowed since last summer, real product has declined slightly, and industrial production has fallen moderately. Employment growth has slackened and unemployment has increased. The primary goal of reduced inflation has not yet been achieved, however, as upward pressure accumulated over the past five years continues to be a powerful influence on current prices. The rate of price increase can be expected to moderate only after the reduced pace of spending and of real economic activity begins to overcome the momentum of inflation.

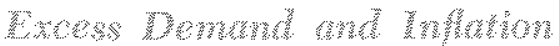

Excessive growth of total spending from 1964 to 1968, fostered by expansive monetary and fiscal actions, resulted in ever-mounting pressure on prices. The response of production to growth of demand for goods and services is limited by the productive capacity of the economy. Production can be expanded by employment of more resources, but as the economy approaches full employment, increasingly less efficient resources are employed, increases in production become more difficult and upward pressure on prices intensifies.

From 1964 to late 1968 , total spending increased at an average 8 per cent rate, while production capacity increased at about a 4 per cent rate. During the early part of the period the economy had resources which could be tapped and consequently production could be increased to meet most of the sudden increase in demand, with little upward pressure on prices. As the unused resources were employed, however, growth of production was constrained and price increases accelerated. Prices rose at a 3 per cent rate from 1965 to mid-1967, a 4 per cent rate from mid-1967 through 1968, and a 5 per cent rate in 1969 .

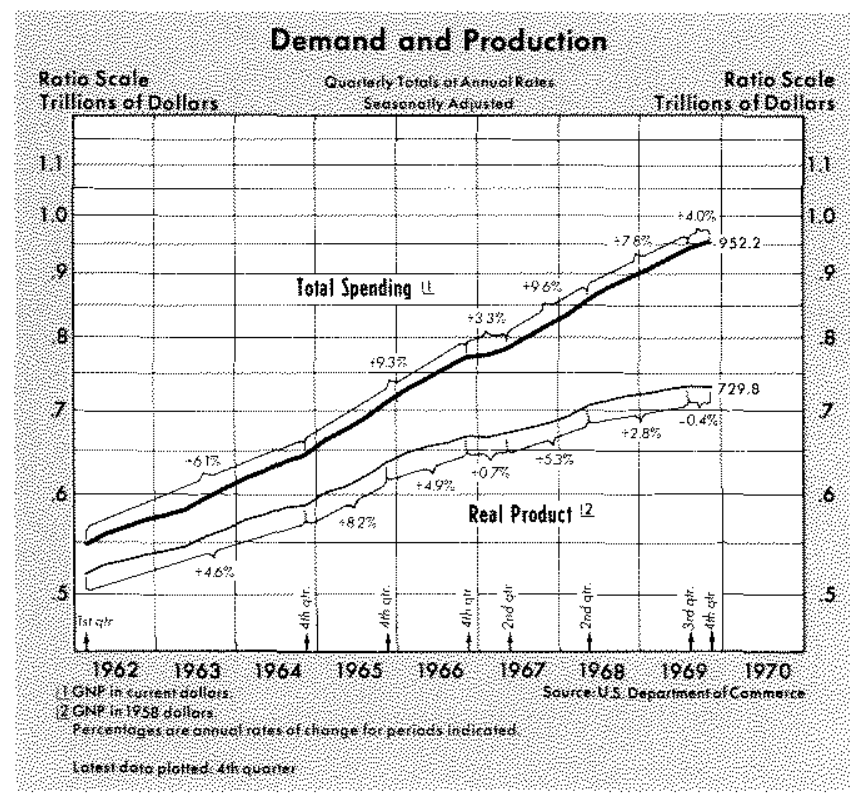

The accelerated growth of total spending was closely related to the rapid monetary expansion, which was apparently undertaken to counter the upward pressure on interest rates being generated by growing Federal government budget deficits and other large demands for credit. The stock of money in the economy was increased at a 5 per cent average annual rate from 1964 to 1968 , markedly faster than the 2 per cent average rate of rise of money in the previous eight years. In the short rum of a few months, increased monetary expansion did help to hold interest rates down by increasing the supply of loan funds. In the longer rum, however, the faster rate of money growth stimulated total spending and price increases and thereby the demand for credit. The overall result was pronounced increases in interest rates.

The tax surcharge and the program of reduced Federal Government expenditure growth adopted in mid-1968 were designed to curb inflation but proved to have much less effect than had been intended. The growth of total spending was not slowed by the 


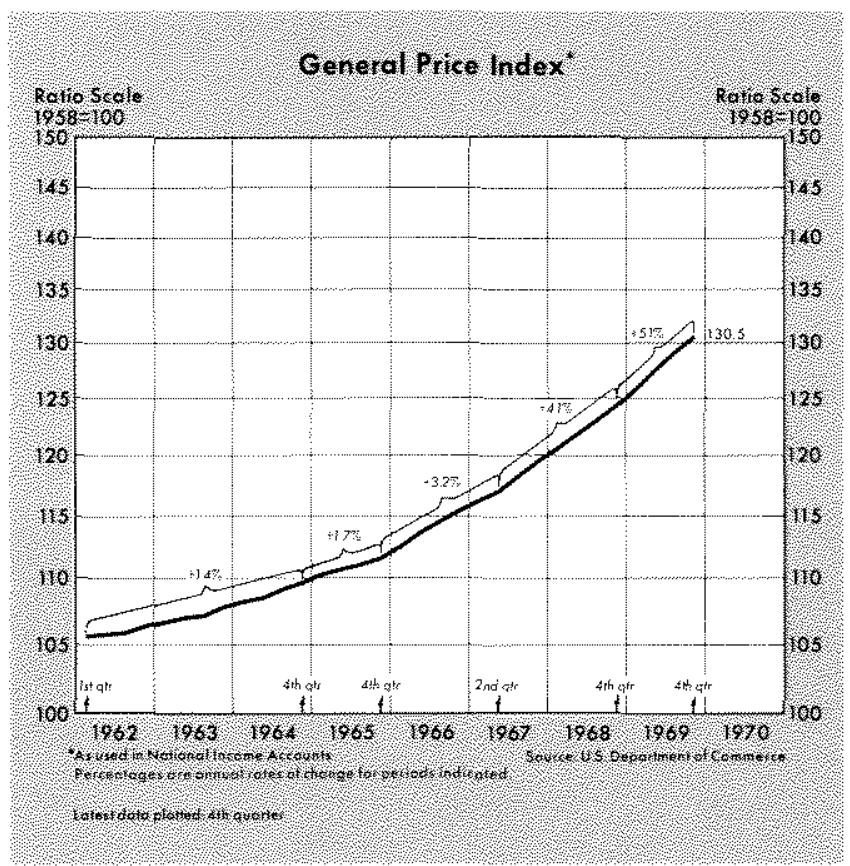

fiscal actions, and the rate of inflation continued to accelerate. The acceleration of price rises was facilitated by stimulative monetary actions as the stock of money continued to grow at a 7 per cent rate from June 1968 to January 1969, following a trend set in early 1967 .

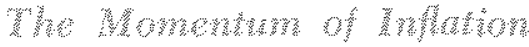

Monetary policy moved toward moderate restraint early in 1969, with money stock growth at a reduced 4 per cent annual rate from January to June. Monetary influence became much more restrictive about mid-1969 - the stock of money remained essentially unchanged through the last half of 1969 . As yet, there has been no abatement of inflation, however, as the impact of the monetary restraint has fallen initially on real economic activity.

Once prices have risen in response to excess demand, actions taken to moderate total spending initially reduce production and have but a delayed effect on prices. In the current situation, inflation was allowed to accelerate for four years before effective restraint was exercised. The longer inflation is allowed to continue, the more resistant it becomes to stabilization actions. Inflation becomes a major factor in expectations and plamning, and is written into wages and other contracts, incorporated into interest rates, and considered in revenue forecasts of investors.

What is often called "cost-push" inflation in our economy today is more accurately the delayed effects of past excessive spending. For example the wage in- creases demanded by labor during recent years, cited as one of the primary factors in pushing up prices, actually reflect, in part, the increasing costs of living experienced in the past few years. ${ }^{1}$ Average hourly wages in manufacturing increased at a 6 per cent annual rate during 1969 but, due to inflation, actual purchasing power of hourly wages was about unchanged. It is this experience which has caused labor to seek wage increases in excess of gains in productivity. These negotiated wage increases appear as increases in unit labor costs and consequently are assumed by some observers to be the cause of inflation. Unit labor costs in manufacturing have been increasing rapidly since mid-1965. However, these costs did not begin to rise sharply until more than a year after prices of industrial commodities began to increase. These "cost-push" factors are a part of the inflationary process and act to further inflation once it has begun. They are more a symptom of demand inflation than an independent influence.

The restrictive monetary action inaugurated early in 1969 and intensified at mid-year resulted in a slowdown of total spending late in the year. Total spending increased at a 4 per cent annual rate from the third to the fourth quarter, down from an 8 per cent rate of increase during the previous two years. The growth of total spending declined further in the first quarter of this year.

Virtually all of the recent moderation in total spending resulted in slowing of real product growth. Real output decreased slightly from the third to the fourth quarter and is expected to show a significant decline in the first quarter. Industrial production has decreased at a 5 per cent annual rate since last July, compared with a 5.7 per cent annual rate of increase over the previous two years.

Along with the moderation of production, growth of employment has declined. Payroll employment, which had expanded at a 3.4 per cent annual rate from mid-1967 to mid-1969, increased at a 1.5 per cent rate from June to October and since October it has increased at a 1.3 per cent rate. Employment in manufacturing has declined sharply since last summer, and the average workweek of those employed has been reduced by almost one hour since late last year. Unemployment has risen since year-end, and reached 4.4 per cent of the labor force in March, higher than the 3.7 per cent average rate of the 19661969 period, but still well below the 5.5 per cent average from 1961 to 1965.

\footnotetext{
1See Albert E. Burger, "The Effects of Inflation (1960-68)", this Review, November 1969, Fp. 25-36.
} 
Personal income grew at a 5.4 per cent rate from August to February, after rising at a 9 per cent rate in the previous year. Since the rate of increase of prices has not slowed, the reduced growth of income represents very little gain in purchasing power. Real personal income, which had increased at a 5 per cent rate from late 1967 to the fall of last year, has since increased at about a 1 per cent annual rate.

\section{The prowh}

The pattern of total spending, real economic activity, and prices in the second quarter of this year has been essentially determined by stabilization actions already taken. Evaluation of the probable path of the economy, including prices, through the rest of the year depends on consideration of most recent and prospective monetary and fiscal actions.

The major contribution of fiscal policy to the current anti-inflation programs has been a sharp reduction in net borrowing by the Federal Government. Large and growing deficits in the 1965-68 period were accompanied by rapid money creation, as the Federal Reserve underwrote much of the newly-created Federal debt. Since late 1968 the Federal budget has generally been in surplus, and the upward pressure on the money stock of large Federal Government financing requirements has been removed. As presented in January, the Government's official budget plan for the fiscal year which begins July 1 indicates a surplus of $\$ 1.3$ billion, about the same as the $\$ 1.5$ billion surplus expected in this fiscal year. The budget is subject to change, however, and items such as the recently proposed postal pay increase could reduce the expected surplus.

Through early February there had been no significant shift in the influence of monetary actions on the economy. The sharp increase in the stock of money in late December was due primarily to technical factors and was offset by a large decline during January. Since early February money has been growing, but the period is still too short to determine whether this is another irregular movement or the beginning of a new trend. If maintained, however, growth of money would tend to provide some stimulus to economic activity late this year.

The declines in interest rates experienced since December apparently reflect reductions in the demand for credit and cannot be interpreted as indicative of a change in the basic impact of monetary actions. Most of the rise in interest rates from 1966 to 1969 was due to rising expectations of inflation as

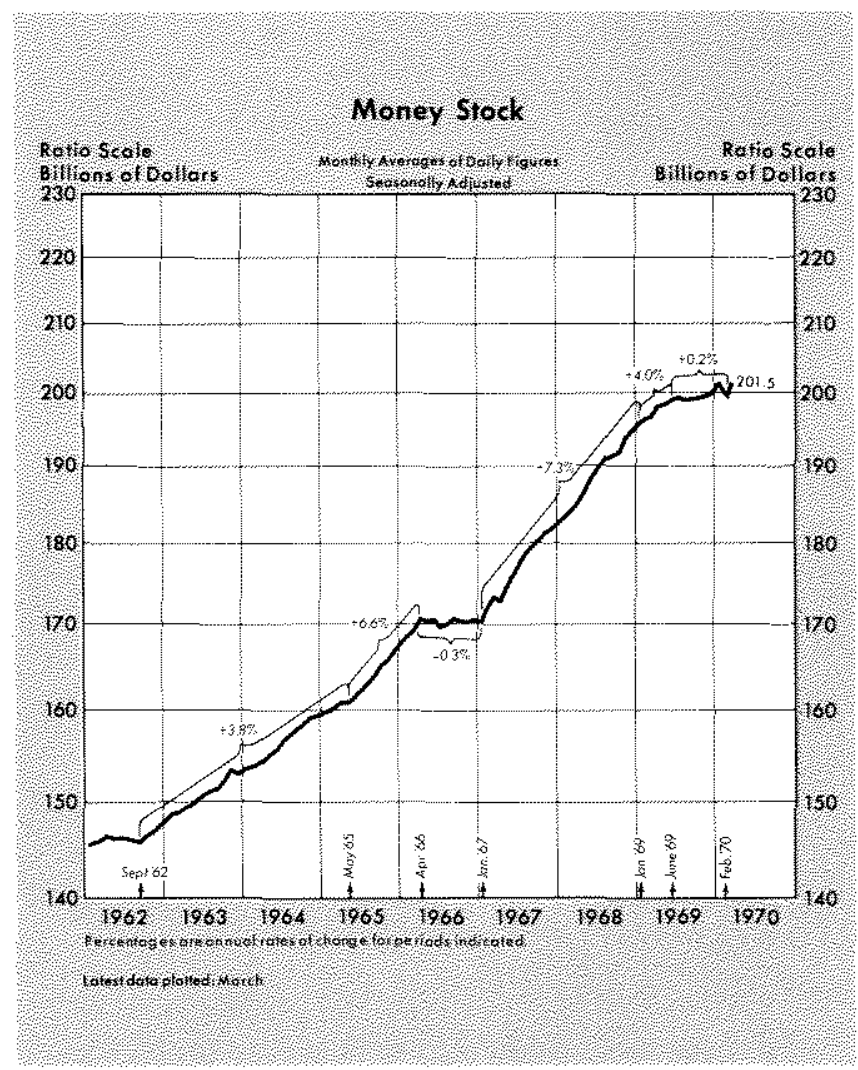

both lenders and borrowers came to expect the value of money to decline. The recent declines in rates have probably been due to the reaction of these market expectations to the signs of increasing weakness in the economy.

Short-term interest rates have declined sharply since early in the year, falling to about the levels of last spring. The market yield on Treasury bills fell from 8.02 per cent in early January to 6.40 per cent in early April. In the spring of last year these bills yielded an average of 6.20 per cent. The interest rate on commercial paper stood at 8.10 per cent in early April, down from an average of 9 per cent early in the year, but above the average 7.55 per cent rate in the spring of last year. Short-term rates in general remain high relative to previous years. The yield on Treasury bills averaged 5.33 per cent in 1968 and 4.30 per cent in 1967. The interest rate on commercial paper averaged 5.90 per cent in 1968 and 5.10 per cent in 1967 .

Long-term interest rates have not shown the marked declines experienced in the short-term market. The yield on corporate Aaa-rated bonds was 7.85 per cent in early April, slightly lower than the January average. Corporate Aaa bonds yielded an average 6.90 per cent last spring, 6.18 per cent in 1968 , and 5.51 per cent in 1967. 


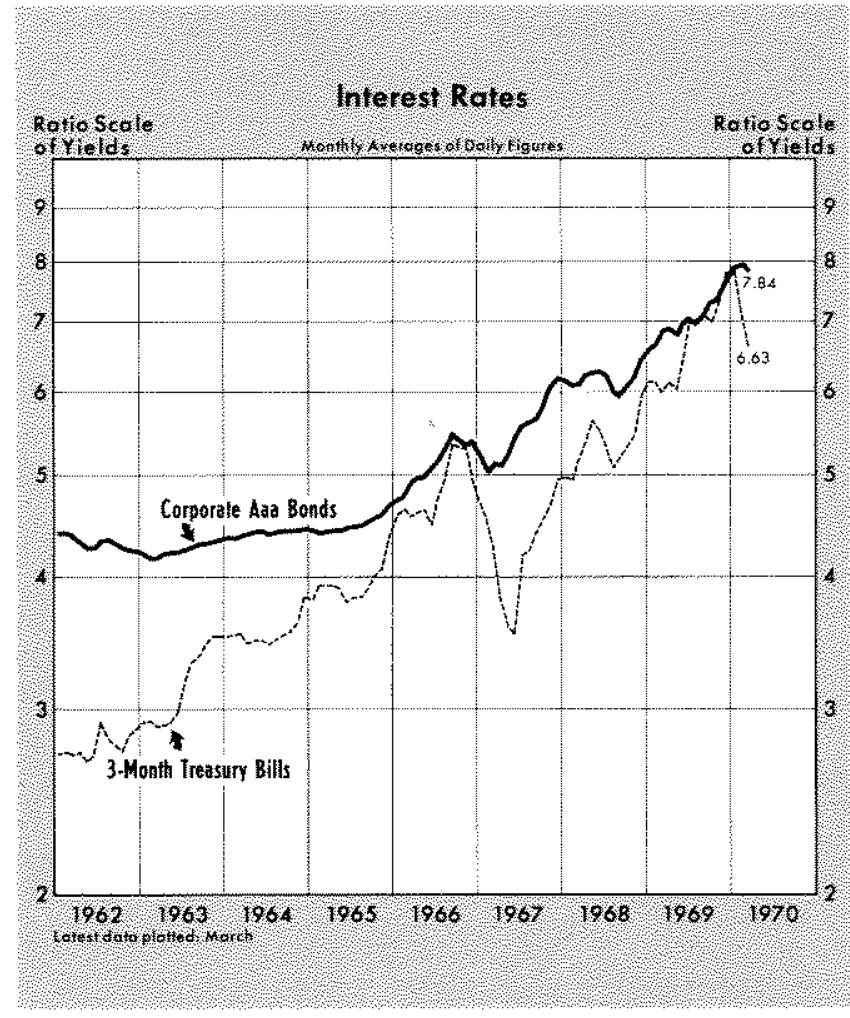

The current slowdown in economic activity should put downward pressure on interest rates. However, it will probably take considerable time to reduce the inflation premium already built into rates, especially on long-term debt. This can only be accomplished through a reduction in the rate of increase of prices. In the current situation long-term interest rates probably cannot be reduced significantly by a large in- crease in the supply of money without a serious risk of further stimulating inflation and causing rates to rise to even higher levels later on.

Research conducted at this Bank (pages 7-25 of this Review) suggests that monetary actions have their major affect on total spending after about two quarters. Accordingly, the policy of monetary restraint in the last six months of 1969 is likely to have a significant impact on total spending through this summer. Because of the momentum of inflation, most of the impact of this restraint will probably continue to be on production and employment. More and more of the lagged effect of monetary restraint should fall on prices, as continued rapid price increases become progressively difficult to maintain in the face of a slowdown in income, spending, and employment.

\section{moneston}

The magnitude and duration of the excessive total spending and inflation in the 1964-69 period have precluded a swift and painless moderation of the rapid rate of price increases. The pressure of accelerating inflation of the last few years is still a strong force pushing upward on current prices, and this effect will have to be overcome first. The restrictive monetary and fiscal actions of the past year have slowed spending, production and income growth, and further slowing is probable. The current inflation is stubborn and cannot be eased quickly, but some moderation in the rate at which prices are increasing is likely later this year.

\section{TRUTH-IN-LENDING FILMSTRIP}

A 20-minute filmstrip on the Truth-In-Lending law and Regulation $Z$ has been made available by the Board of Covernors of the Federal Reserve System. This new filmstrip, and an earlier film intended for creditors, may be borrowed free of charge from the Bank Relations and Public Information Department of the Federal Reserve Bank of St. Louis.

The filmstrips are designed to be used with a Dukane or similar projector which simultaneously views the $35 \mathrm{~mm}$ film and plays a $33 \% 3$ RPM record. Film changing is synchronized with the narration. The projector is not furnished with the filmstrip, but it is understood that such equipment is widely available.

When submitting requests for the filmstrip, please indicate the date desired with alternates and the approximate number of the expected audience. Copies of an informative booklet for consumers, entitled "What Truth-In-Lending Means To You," will accompany the filmstrip. 